\title{
Focal photoparoxysmal response in the Heidenhain variant of CJD
}

Hidden from view!

Figure EEG and radiologic findings in the Heidenhain variant of Creutzfeldt-Jakob disease

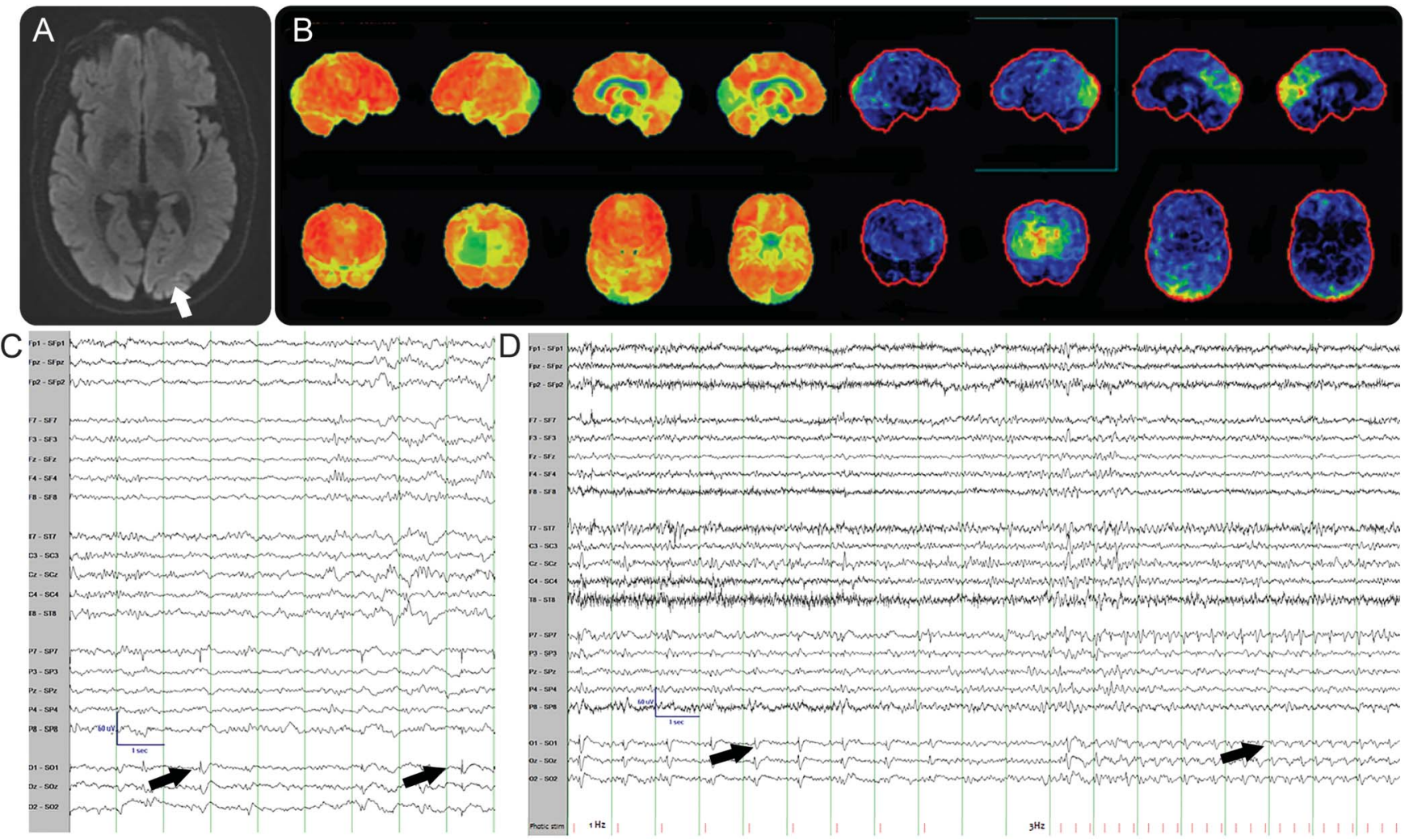

Axial diffusion-weighted MRI showing hyperintensity (arrow) in the left occipital cortex (A). Fluorodeoxyglucose-PET demonstrating marked hypometabolism in the bilateral occipital lobes, maximal on the left (B). EEG during sleep depicting periodic left parietooccipital spikes (arrows) (C) and left occipital photoparoxysmal response (arrows) during low-frequency stimulation (D).

A 73-year-old, right-handed man presented with new-onset right visual field diminution and visual hallucinations. Examination showed a right homonymous hemianopia without cognitive impairment. Brain imaging showed left occipital cortex abnormalities (figure, A and B). EEG showed sleep-predominant, periodic left occipital spikes and an occipital photoparoxysmal response (figure, C and D). A second-generation RT-QulC (real-time quaking-induced conversion) test detected pathogenic prion proteins in the CSF, confirming Creutzfeldt-Jakob disease (CJD).

The Heidenhain variant of $\mathrm{CJD}^{1}$ is characterized by visual disturbances as the presenting feature and marked neuropathologic abnormalities involving the occipital cortices. EEG findings include occipital and generalized periodic sharp complexes. ${ }^{2}$ Sleep activation and photoparoxysmal activity have not been reported.

Anteneh M. Feyissa, MD, MSc, Elaine C. Wirrell, MD, David T. Jones, MD, Nathan P. Young, DO, Jeffrey W. Britton, $M D$

From the Department of Neurology (A.M.F., D.T.J., N.P.Y., J.W.B.), Mayo Clinic, Rochester; and Division of Child and Adolescent Neurology (E.C.W.), Mayo Clinic Children's Center, Rochester, MN.

Author contributions: Study concept and design: Drs. Feyissa, Wirrell, and Britton. Acquisition of data: Drs. Feyissa, Wirrell, Jones, Young, and Britton. Drafting of the manuscript: Dr. Feyissa. Critical revision of the manuscript for important intellectual content: Drs. Wirrell, Jones, Young, and Britton. 
Study funding: No targeted funding reported.

Disclosure: The authors report no disclosures relevant to the manuscript. Go to Neurology.org for full disclosures.

Correspondence to Dr. Feyissa: feyissa.anteneh@mayo.edu

1. Heidenhain A. Klinische und anatomische Untersuchungen über eine eigenartige organische Erkrankung des Zentralnervensystems im Praesenium. Z Ges Neurol Psychiatr 1929;118:49-114.

2. Kropp S, Schulz-Schaeffer WJ, Finkenstaedt M, et al. The Heidenhain variant of Creutzfeldt-Jakob disease. Arch Neurol 1999; 56:55-61.

\section{Subspecialty Alerts by E-mail!}

Customize your online journal experience by signing up for e-mail alerts related to your subspecialty or area of interest. Access this free service by visiting Neurology.org/site/subscriptions/etoc.xhtml or click on the "E-mail Alerts" link on the home page. An extensive list of subspecialties, methods, and study design choices will be available for you to choose from-allowing you priority alerts to cutting-edge research in your field!

\section{Save These Dates for AAN CME Opportunities!}

Mark these dates on your calendar for exciting continuing education conferences by the American Academy of Neurology.Learn more at AAN.com/conferences.

\section{Sports Concussion Conference}

- July 8-10, 2016, Chicago, IL, at the Hilton Chicago

Fall Conference

- October 14-16, 2016, Las Vegas, NV, at the Cosmopolitan of Las Vegas

\section{Minutes Pack a Punch}

\section{Neurology ${ }^{\circledR}$ Podcasts}

- Interviews with top experts on new clinical research in neurology

- Editorial comments on selected articles

- Convenient-listen during your commute, at your desk, or even at the gym

- On demand-it's there when you want it

- Fun and engaging

- New topic each week

- FREE

Listen now at www.aan.com/podcast 


\section{Neurology}

Focal photoparoxysmal response in the Heidenhain variant of CJD: Hidden from view! Anteneh M. Feyissa, Elaine C. Wirrell, David T. Jones, et al.

Neurology 2016;86;1647-1648

DOI 10.1212/WNL.0000000000002617

\section{This information is current as of April 25, 2016}

Updated Information \& Services

References

Subspecialty Collections

Permissions \& Licensing

Reprints including high resolution figures, can be found at: http://n.neurology.org/content/86/17/1647.full

This article cites 2 articles, 0 of which you can access for free at: http://n.neurology.org/content/86/17/1647.full\#ref-list-1

This article, along with others on similar topics, appears in the following collection(s): All Cognitive Disorders/Dementia http://n.neurology.org/cgi/collection/all_cognitive_disorders_dementia EEG

http://n.neurology.org/cgi/collection/eeg

Hallucinations

http://n.neurology.org/cgi/collection/hallucinations

Prion disease; see Infections/prion

http://n.neurology.org/cgi/collection/prion_disease

Visual fields

http://n.neurology.org/cgi/collection/visual_fields

Information about reproducing this article in parts (figures,tables) or in its entirety can be found online at:

http://www.neurology.org/about/about_the_journal\#permissions

Information about ordering reprints can be found online:

http://n.neurology.org/subscribers/advertise

Neurology ${ }^{\circledR}$ is the official journal of the American Academy of Neurology. Published continuously since 1951, it is now a weekly with 48 issues per year. Copyright (O 2016 American Academy of Neurology. All rights reserved. Print ISSN: 0028-3878. Online ISSN: 1526-632X.

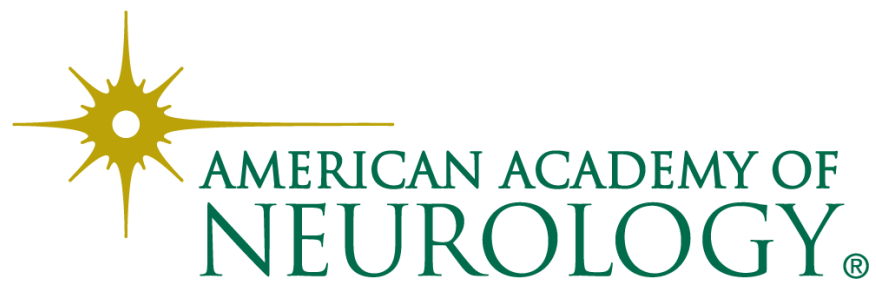

